\title{
Violence against Women in Politics: A Study of Backlash Effect of Gender Quota in Parliament of Pakistan
}

\author{
* Dr. Sher Muhammad, Assistant Professor \\ ** Dr. Muhammad Waris Awan, Assistant Professor (Corresponding Author) \\ **** Misbah Hussain, Ph.D. Scholar
}

\begin{abstract}
This paper intends to explore the "backlash" impact of gender equality policies such as gender quotas in the shape of the resistance, provoked by male parliamentarians against their female colleagues. Such resistance exists in different shapes, such as sexist remarks, intimidation, or harassment. It is important to understand the nature and the motive behind such type of violence, and how do women legislators view such tactics. The research paper is primarily based on semistructured interviews with 15 female members of the National Assembly of Pakistan. It is evident from the findings of the paper that patriarchy, socio-economic structures, and the political power configurations are key elements that lead to this type of violence and it is not peculiar to only women elected on reserved seats.
\end{abstract}

Keywords: Gender Equality, Patriarchy, Harassment, Intimidation, Socio-Economic Structures, Violence

\section{Introduction}

The practice of violence against women is commonly found in all societies ranging from the most primitive to the most modern ones. It cuts across all kinds of cultural, regional, religious, and economic divides that exist in the world. Male-dominated political institutions always attempt to restrict women's entry into politics as a group that is a serious threat to the rights of half of the world population. Yet as more and more women are claiming their right to equal participation and representation in political institutions around the world, the backlash has intensified and become more visible (Biroli, 2018). In recent years, an increase has been observed in cases of various types of violence directed at female politicians (Krook, 2018). Gender-motivated Political Violence (GMPV) aims to suppress the political rights of the victims because of the victim's gender. This type of violence infringes an individual's or groups' political rights based on their gender identity. Scholars have identified five forms of violence against female politicians: physical, sexual, psychological, economic, and symbolic (Krook, 2017) but recently another category semiotic has been identified (Krook and Sanin, 2019). These all types of violence are the various manifestation of the same type of behaviors, having only one objective to restrict women's participation in politics.

Table 1: Types of Violence

\begin{tabular}{ll}
\hline Type of Violence & Definition \\
\hline Physical Violence & $\begin{array}{l}\text { In this type of violence, physical injuries are caused to female politicians or their } \\
\text { family members. It may include domestic abuse, beating, abduction, and even } \\
\text { assassination }\end{array}$ \\
It comprises unwelcome sexual comments or advances, including sexual harassment, \\
rape, and sexual exploitation.
\end{tabular}

* Department of Political Science, Government College Bhalwal, Sargodha, Pakistan

Email:phdscholer2010@gmail.com

** Department of History and Pakistan Studies, Government College University, Faisalabad, Pakistan

*** Department of History and Pakistan Studies, Government College University, Faisalabad, Pakistan 

aggression at the level of representations

Sources: Krook and Sunin, 2019; Krook, 2017

For the prevention of such types of violence, it is important to identify and understand the agents who commit such acts of violence. Several perpetrators may be identified who may belong to more than one category. It is the responsibility of the state to protect women from these perpetrators and punish the instigators of violence and providing recourse and services to victims. These perpetrators are likewise diverse and may be identified in three groups.

Table 2: Perpetrators

\begin{tabular}{lll}
\hline Societal Actors & Political Actors & State Actors \\
\hline Journalists/media & Candidates & State security actors (police, \\
Voters & Party leaders & armed forces) \\
Community members & Interparty & Government institutions \\
Groups & Intraparty members & (executive, justice sector, \\
Religious leader & Paramilitary & legislature) \\
Local leaders & Party militia & Election officials, workers, and \\
Employers & Non-state armed actors & security \\
Criminal actors & & State proxies (militia, gangs, \\
Intimate partners/ spouses & & insurgents, private security) \\
Family members & & \\
Electoral observers & & \\
Youth groups. & & \\
\hline
\end{tabular}

Source: Bardall, 2013; also see Huber \& Kammerud, 2016.

Motives for Violence against Women in Politics (VAWIP)

With a weak legal system, religious extremism, and misuse of socio-cultural values, women in Pakistan do suffer in different ways. There are systematic seclusion and exclusion of women due to socio-cultural norms based on patriarchal values which eventually negates access to political institutions. It is argued that male perception about the role of women is the foremost cause that restricts the empowerment and autonomy of women. Ashfer (2005) concludes that "women have been relegated to the private sphere, subsumed within the household, headed by the individual male". Women are treated as an inferior creature, having no rights and privileges. Even women are considered to remain silent against violence by men. The female body is always controlled by male relatives. This depressed social customs outcome in an organized marginalization of women in politics and also curtail the political choices for them. Women are told again and again that they should stay inside the boundaries (Chardivari) of the home and if she will go outside, this might bring some dishonor for the family. These factors also become a pretext for gender-based violence because it produces a sense of male supremacy. Although after the adoption of the gender quota in Pakistan, landmark legislation has been made on the women-specific issue women are still facing this type of violence ${ }^{1}$.

Available statistics support the argument that the number of incidents of violence against women in politics is increasing. One study has found that nearly all-female legislators have experienced various types of violence in the course of their parliamentary work (Inter-Parliamentary Union, 2016). Such types of violence are also found at national and local level politics. In Malawi in the 2009 elections, 225 women candidates out of 425 withdrew nomination papers before the elections due to harassment and intimidation (Semu-Banda, 2008). National Democratic Institute (2010) found that nearly all-female candidates had received threatening phone calls during the general elections of 2010 in Afghanistan. Another study (Bjelica \& Sorush, 2018) in Peru found that $41 \%$ of female aspirants in local government institutions faced violence. It is astonishing that in Bolivia, 70\% of women politicians had faced such type of violence more than once (Krook, 2018). The violence

\footnotetext{
${ }^{1}$ Criminal Law (Amendment) Act, 2004 (Honour Killing); Protection for Women (Criminal Law Amendment) Act, 2006; The Protection Against Harassment of Women at the Workplace Act, 2010; Criminal Law Amendment Act, 2010 (Sexual Harassment); Criminal Law (Second Amendment) Act, 2011; The Prevention of Anti Women Practices - Criminal Law (Third Amendment) Act, 2011 and Domestic Violence (Prevention and Protection) Act, 2012
} 
against women politicians is not just an issue of developing countries but even in established democracies like New Zealand, $80 \%$ of female legislators reported that they have experienced at least one of these forms of harassment (James et al. 2016). It was reported that such incidents forced British female legislators to increase their security arrangements at home (James et al. 2016, p.186). Canadian female politicians also described these interventions as "frightening" or "terrifying" (Adams et al. 2009, p.807).

Figure 1: Types of Violence against Women in Politics in Pakistan (Percentage)

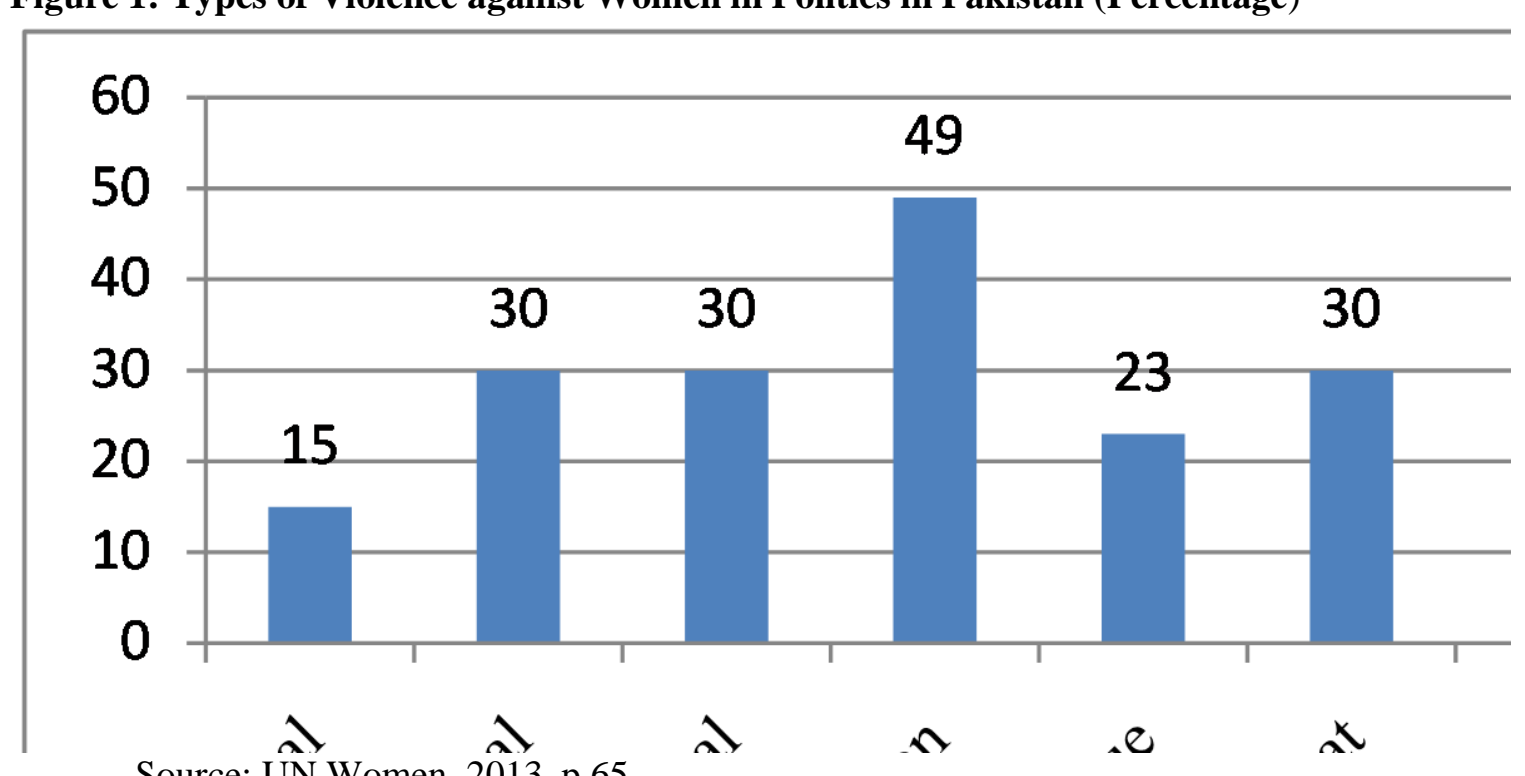

Source: UN Women, 2013, p.65

It is evident from Figure 1 that character assassination is the greater threat of violence against women in politics. A comparative study of violence against women in politics in South Asian countries found that fear of such type of violence is a serious concern for almost 60 percent of women before making any decision to become a candidate (UN Women, 2013).

\section{Methodology}

This paper is based on semi-structured interviews with key stakeholders including women elected on reserved seats and women rights activists. Efforts have been made to incorporate the views of different categories of respondents. This qualitative survey will ensure to have views of elected female legislators for a better understanding of the issues of violence against women in politics.

\section{Backlash Effect of Gender Quota in Pakistan}

The foremost objective of affirmative measures like gender quotas is to increase women's participation and representation in mainstream politics because this can help to transform maledominant structures of political institutions. Male politicians always consider such policies as a threat to their power as traditionally everything is taken by them as a right, not a privilege. These male politicians often react to maintain political power when they observe a sharp increase in women's numbers in the parliaments. It is an important issue to explore whether these positive opportunities for women also present further limitations for quota women when they try to bring reforms that benefit women as a group.

In fact, contrary to women's participation is a positive thing for women, this shift and increased participation might be taken as a threat in third world countries to the male-dominated environment of the Parliament. Zetterberg (2008) mentioned two major types of backlash from male politicians. First, male party leaders select inexperienced and ineffective women because that will help them to retain their control over the political institutions. Secondly, they make efforts to assign women less prestigious positions in the Parliament to keep these quota legislators from exercising any substantive political influence. Another scholar argued that a gender-responsive institutional environment is critical for the successful execution of women's substantive representation (Busche, 2010). The understanding of institutions is also an important component for the analysis of the effectiveness of any gender equality policy.

Traditionally politics is considered a male domain and women are forced to stay at home and let males do the politics but over time, women demanded equal political rights and share in decision 
making. In many societies, males used different types of violence to keep women out of political activities. After the adoption of the gender quota in 2002 in Pakistan, a substantive increase was observed in women's representation in the parliament. It is argued that it is essential to analyze the importance of institutional power structure by explaining women's access and utilization of power and influence in decision-making processes (Petersson, 1988, p. 147). Certain official institutions have more advantaged powerful positions compared to others. This led to the temptation for all members without gender discrimination, to want to be a part of such institutions. The logic behind these analyses is to look into or reassess the precise positions which female Member of National Assembly (MNA) occupies in the governance institutions of Pakistan. It is also critical to explore the ways women have used to apply such power to manipulate gender-related legislation on different issues. It has been acknowledged that due to having less effective positions in decision making, women do not usually asset adequate impact to change unfavorable policy (Henig and Henig, 2001). Another tactic that is used to keep women out of the corridor of power is to assign them less privileged positions in the cabinet. A study conducted by the UN observed that women are always given responsibility in social areas rather than in important economic or political ones (UN, 1992). Similarly, it is argued that soft ministries like social affairs, welfare, education, and health are considered the most suitable for them because these ministries have less power and prestige than, for example, financial portfolios (Henig and Henig, 2001).

\section{Findings}

There is a certain type of social, political, and economic inequalities and rural-urban divide in Pakistani society. Certain other dynamics like social customs and practices had continued to harm the lives of women in Pakistan. Pakistani women exercise little power either over themselves or on matters distressing their welfare. Having legal safeguards, they are treated as possessions and not a self-reliant human. They are dispossessed and disinherited. Local culture and traditions have a strong influence on their status in society. The institutional context in Parliament is another significant dynamic that shapes the parliamentary performance of the female legislators. It is argued that Substantive representation occurs in multiple stages of the legislative process. Legislative outcomes of the parliament are influenced not merely by the sex of the representation but by the gendered power relations that are reflected in the institutional rules, operating procedures, and informal norms of the legislative bodies (Franceschet and Krook, 2008, p. 16).

While analyzing the effectiveness of such gender equality policies, it is crucial to observe and understand the parliamentary environment as it is directly linked with the occurrence of women's substantive representation. For a better understanding of this issue, it is important to know the views of female legislators about fear of violence inside the Parliament of Pakistan. The responses of women legislators support the argument presented by Tamale $(2000$, p. 12) that institutional frameworks influence the way female MNAs participate in parliamentary business and it can be responsible for gender inequality. A female MNA informed the researcher that sometimes she does not feel comfortable to speak in the male-oriented legislature because they do not take their speeches seriously. She asked for a parliamentary norm to allow women to speak first, and that males should not interrupt them. She further pointed out that she experienced such a hostile situation while she once introduced a motion on women's issues. A female MNA from an opposition party informed that Parliament should not be an arena for gender dominance rather a forum where women are empowered to be part of all major political decisions. She further told that sometimes women's numbers made her frustrated because women do not have the majority to make any change in Parliament in comparison to men. On the other hand, men have the majority vote to pass favorable legislation. She believes that "a simple rule prevails in the Parliament; the success of your legislative intervention depends on the liking and support of male legislators". A female MNA from a major political party and also a women's rights activist too proposed institutional reforms to make parliament more women-friendly. She pointed out that:

National Assembly is an important House of parliament where women can make new laws that can advance women's welfare. However, Female MNAs faced gender discrimination on many occasions. They were not giving due media coverage of their parliamentary work. It means that the public could not have an assessment of the parliamentary proceedings and activities. There is a need for parliamentary reforms that engender its structures, including rules of business that ensure 
everyone participates equally without fear of any discrimination based on gender (personal Interview $)^{2}$.

Another woman legislator exposed another dimension of the issues. She claimed that women legislators always look at the environment of the parliament because sometimes, the legislative bill can be accepted and sometimes not. If a woman member feels that there is a conducive atmosphere for a debate on gender matters, then she tries to participate in debate or submit a legislative bill. An opposite intention was expressed by another female MNA, who claimed that party policy is a key factor for the success of any legislative activity. There are chances that if male members do not like the legislative intervention of a female member, they can use derogatory remarks against that female legislator. There are certain incidents when male members call the names of female legislators ${ }^{3}$.

During the interviews with female legislators, most of them agreed that male colleagues most of the time listened to them. They further pointed out that this is based on relationships of mutual respect. A female Legislator who was elected on women's reserved seats from a religious political party thought that personal identity plays a major role. Her father was a prominent political figure and head of a major religious political party. He had great respect in the parliament. When she was elected to women's reserved seats, she received due regard and respect from male members of the Parliament. She pointed out an important aspect that "if female legislators wear a modest dress, then there is fewer chances of derogatory remarks from the male benches" but the majority of female MNAs do not support this argument. They argued that the dressing of MNA is not a concern.

One woman interviewed highlighted that party leadership always consider their views on political issues. They feel very relaxed while sitting and working with their male colleagues. They have superb working relations with their male colleagues who always give them due respect. She termed it "teamwork" and asked for collective efforts for the smooth working of Parliament. She quoted a few incidents of meetings of Standing Committees when male legislators listened to their arguments and respected their views. She believes that these "bodies are not a battlefield, but negotiation tables". But these views do not illustrate the entire story because a few others having mainly negative experiences. One female MNA commented that whenever we have a good proposal or legislative bill or when we try to demonstrate that we are also qualified members of Parliament, male members to a certain extent, get troubled. They use strange tactics. They try to ignore us by paying no attention to our opinion. Once I was speaking, but they were busy in personal talk or a few of them were sleeping. They want to express that our speeches are not important to listen to. One women rights activist claimed that many male parliamentarians are more feminist than women legislators. He believed that a good legislator always works on diverse issues. There must not be a division of issues based on sex. He was much satisfied with his presence and performance in the house. He pledged that they have supported and will continue to support women's issues.

A women's rights scholar expressed her strong optimism about the performance of female legislators, and she appreciated their efforts. These elected female MNAs had a challenging job of working on women's rights in a male-dominated parliament. She argued that female legislators are acting for the common good of women. First time in parliamentary history, a huge number of Private Member Bills (PMBs) were submitted. She pointed out that there had been other important developments that these women were concerned about and interested in the hardcore issues like finance, foreign policy, environment, and governance.

Violence against women has serious consequences for women's substantive representation. Few female legislators agreed with the above statement but claimed that in the parliament of Pakistan, males do not use such type of violence against women. They consider women having equal respect and rights as members of the Parliament. Many female legislators also supported the statements made by male members that they do not feel any fear of violence while working as members of the parliament. There were diverse responses about the behavior of the male legislators.

\footnotetext{
${ }^{2}$ Interviews with Legislators were conducted in $2014-15$ by the fist author. Efforts have been made to hide the identity of participants, and for that purpose, real names of the MNAs have not been disclosed.

${ }^{3}$ Khawaja Asif called names of Female members of PTI. For details read https://www.dawn.com/news/1339297 and https://dailytimes.com.pk/77196/na-uproars-khawaja-asif-calls-shireen-mazari-aunty-tractor-trolley
} 
There is another dimension to this issue. In Pakistan, women do not like to express such incidents of sexual abuse and violence with strangers and in public. If any incident has happened, she will discuss it with her close friends and might be with family. Female legislators indirectly said that such type of violence is used in the parliament but no one was ready to share details of any incident. It has been evident from the talk of female legislators that psychological violence was most common in the politics of Pakistan. Male have used such type of violence to restrict female legislators' participation in legislative business and in such cases, male legislators mostly give derogatory remarks against female parliamentarians. It is argued that "NA sessions regularly dissolve into chaos after lawmakers, unable to politely disagree with each other, can be seen yelling across the room, name-calling, making sexist and 'vulgar' remarks, and staging protests and walkouts" (Dawn, 13 April 2017)

It was also observed that younger legislators have to listen to such comments more frequently. Another important indicator that has helped women to feel more comfortable in parliament was their numerical representation. Gender quota policy has brought a significant number of (critical Mass") ${ }^{4}$ women that worked as protecting shield against violence, It is argued that "insufficient implementation of laws, lack of support from police and judiciary, the socioeconomic divide and current power structures are the major reasons for violence" (UN Women, 2013). The above responses suggest that the rules and informal norms of the Parliament are strongly connected to women's substantive representation. These women will not be able to have a substantive impact until a favorable environment is provided.

\section{Conclusion}

Violence against women in politics is considered a significant barrier to women's effective working in parliament. The present study has examined this issue in the parliament of Pakistan. The majority of the women legislators claimed that they do not feel any fear of violence while working as members of the parliament but claims are negated by the several incidents published in media when male legislators gave derogatory remarks about female legislators. It looks that the adoption of gender quota in Pakistan has helped women to get a substantive increase in their representation and this "critical mass" of women has been a protective shield against such type of violence. These dynamics work to obstruct the political empowerment of women. There are varied manifestations of this critical problem and it demands a multifaceted solution. Several countries like Pakistan have new legislation to combat physical, psychological, and economic violence against women. It is also necessary to cultivate stronger parliamentary codes of conduct to feel women legislators comfortable while participating in parliamentary business.

\section{References}

Adams, S.J., Hazelwood, T.E., Pitre, N.L., Bedard, T.E., \& Landry, S.D. (2009). Harassment of members of parliament and the legislative assemblies in Canada by individuals believed to be mentally disordered. The Journal of Forensic Psychiatry \& Psychology, 20(6), 801-814.

Afshar, H. (Ed.). (2005), Women and politics in Third World. London: Rutledge.

Bardall, G. (2013). Gender-Specific election violence: The role of information and communication technologies. Stability: International Journal of Security and Development, 2(3).

Biroli, F. (2018). Violence against women and reactions to gender equality in politics. Politics \& Gender, 14(4), 681-685.

Bjelica, J., \& Sorush, R. (2018). Afghanistan Elections Conundrum (20): Women candidates going against the grain. Afghan Analyst Network.

Busche, H. (2010). The Missing link: Examining the relationship between the descriptive and substantive representation of women in the UK. Western Political Science Association Annual Meeting Paper.

Childs, S., and Krook, M. L., (2008). 'Critical Mass Theory and women's political representation', Political Studies 56, pp. 725-36.

Franceschet, S., and Krook, M. L. (2008, August). Measuring the impact of quotas on women's

\footnotetext{
${ }^{4}$ This theory focuses primarily on the numerical representation of women. Childs and Krook (2008) claim that women legislators cannot impact legislative politics until they have a "critical mass" of elected representatives. The central argument of the available literature on critical mass theory is that increasing the percentage of women's seats results in women friendly legislations.
} 
substantive representation: Towards a conceptual framework. Paper presented at the Annual Meeting of the American Political Science Association, Boston, MA.

Henig, R. B., \& Henig, S. (2001). Women and political power: Europe since 1945. Psychology Press.

Huber, J., \& Kammerud, L. (2016). Violence against women in elections, an excerpt from IFES' Framework. International Foundation for Electoral Systems. Available at https://www.ifes.org/sites/default/files/2016_ifes_violence_against_women_in_elections.pdf

Inter-Parliamentary Union (2016). Sexism, harassment, and violence against women parliamentarians. Issues Brief. http://www. Ipu. Org/pdf/publications/issues brief-e. Pdf (March 28, 2017).

James, D. V., Farnham, F. R., Sukhwal, S., Jones, K., Carlisle, J., \& Henley, S. (2016). Aggressive/intrusive behaviors, harassment, and stalking of members of the United Kingdom parliament: a prevalence study and cross-national comparison. The Journal of Forensic Psychiatry \& Psychology, 27(2), 177-197.

Krook, M. L. (2017). Violence against women in politics. Journal of Democracy, 28(1), 74-88.

Krook, M. L. (2018). Violence against women in politics: A rising global trend. Politics \& Gender, 14(4), 673-675.

Krook, M. L., \& Sanín, J. R. (2019). The Cost of Doing Politics? Analyzing Violence and Harassment against Female Politicians. Perspectives on Politics, 1-16.

National Democratic Institute (2010). The 2009 Presidential and Provincial Council Elections in Afghanistan. Washington, DC: National Democratic Institute.

Petersson, O. (1988), 'The study of power and democracy in Sweden', Scandinavian Political Studies 11(2), 145-158.

Semu-Banda N.P. (2008). "Politics-Malawi: Elections Get Ugly for Women." IPS News, November 24. http://www.ipsnews.net/2008/11/politics-malawi-elections- get-ugly-for-women/.

Tamale, S. (2004). Gender trauma in Africa: Enhancing women's links to resources. Journal of African Law, 48(01), 50-61.

UN Women (2013), Violence against women in politics: A study conducted in India, Nepal, and Pakistan. New Dehli: Center for Social Research.

United Nations (1992). Women in politics and decision-making in the late twentieth century: A United Nations study. https://www.un.org/womenwatch/daw/beijing/beijingat10/G.\%20Women\%2 0in\%20power\%2 and\%20decision-making.pdf

Zetterberg, P. (2008). 'The downside of gender quotas? Institutional constraints on women in Mexican state legislatures', Parliamentary Affairs, 61(3). 442-60. 